with 10 cases of occupationally acquired HIV infection $(0.16 \%)$. Rates of $0.25 \%(9 / 3,628)$ after percutaneous exposures and $0.09 \%(1 / 1,007)$ after mucous membrane exposures represent the best available estimates of the magnitude of risk of occupationally acquired HIV infection.

FROM: Ippolito G, Puro V, De Carli G, et al. The risk of occupational hiv infection in HCWs. A rch Intern Med 1993;153:1451-1458

\section{HIV Key Receptor Identified}

A French research team at the Pasteur Institute, headed by Dr. Ara Hovanessian, has identified a "co-receptor" molecule, named CD26, used by all strains of HIV to gain entry into blood cells. Since 1984, the CD4 receptor molecule has been known as the site of attachment on the surface of some blood cells. However, it was unknown how the virus moved inside the cell. This discovery that both the CD4 and CD26 molecules are necessary for the virus to penetrate and infect a cell could lead to the development of a vaccine to lock out the virus.

Just days after the French researchers made their announcement about the discovery of the "gateway" molecule, CD26, Australian scientists cloned the gene that makes the CD26 molecule and have invited the Pasteur Institute to share the clones.

John-Paul Levy, head of France's National AIDS Research Center, said the findings represent a major breakthrough because of implications for a vaccine that would work against all HIV strains.

\section{Universal Vaccination Urged as Incidence of Penicillin-Resistant PneumococciIncreases}

Until recently, clinical isolates of pneumococci that were penicillin resistant were rare. However, recent nationwide surveys of U.S. isolates revealed that $4 \%$ to $5 \%$ of the clinical isolates of Streptococcus pneumoniae either were resistant intermediately or highly resistant to penicillin. In a recent review article, Dr. Gregory Caputo et al from Presbyterian Medical Center in Philadelphia warn clinicians that this development has significant implications for treating patients with suspected or documented pneumococcal infections. They suggest that the current evidence supports the use of vancomycin as the therapeutic agent of choice, reserving third-generation cephalosporins for selected cases in which in vitro susceptibility of the infecting strain is confirmed.
Finally, the authors suggest that the threat of further increases in the incidence of penicillinresistant pneumococcal infection should serve as added support for the goal of universal pneumococcal vaccination in high-risk patients.

FROM: Caputo GM, Appelbaum MD, Liu HH. Infections due to penicillin-resistant pneumococci. Arch Intern M ed 1993;153:1301-1310.

\section{Preoperative $S$ aureus Colonization of Nares a Risk Factor for Saphenous Vein Harvest Site Surgical Wound Infection}

A recent study suggests that Staphylococcus aureus colonization of the nares and sternum may contribute to saphenous vein harvest site surgical wound infections (SVHSWI). Since November 1990, patients undergoing coronary artery bypass grafting at the University of Iowa have been enrolled in a surgical wound surveillance study. The nares were cultured preoperatively and the sternal wounds cultured within three days of surgery. Postoperative venectomy wounds were inspected twice weekly, and cultures were obtained from all abnormal wounds. Infections were identified by a concurrent infection control surveillance system using standard definitions.

From 1991 to 1993, 87 patients developed SVHSWI. S aureus was isolated from $36 \%$ of the infections. Paired isolates of $\mathrm{S}$ aureus from nasal or sternal wound surveillance cultures and from postoperative SVHSWI were available from nine patients. All isolates were typed by restriction endonuclease digestion of plasmid DNA (Clal; REP-PDNA) and of chromosomal DNA (Smal: pulsed-field gel electrophoresis [PFGE]). In eight of nine patients, the REP-PDNA of the preoperative isolate matched the REP-PDNA of the postoperative SVHSWI isolate. PFGE typing confirmed these results.

These findings suggest that $S$ aureus carried in the nares and on the sternum can contaminate and infect distal surgical wound sites. The researchers suggest that preoperative screening for carriage and possibly decolonization might decrease the risk of surgical site infections.

FROM: Morales E, Herwaldt L, Sanford L, et al. The role of Staphylococcus aureus carriage in saphenous vein harvest site surgical wound infections. 33rd Interscience Conference on Antimicrobial Agents and Chemotherapy; New Orleans, LA; October 1720, 1993. Abstract 1446. 